\title{
BEHAVIOR-BASED PARTICIPATION IN PARTICIPATORY PROGRAM MANAGEMENT ON LOCAL GOVERNMENT IN THE PROVINCE OF LAMPUNG
}

\author{
Dedy Hermawan \\ Jurusan Administrasi Negara \\ FISIP, Universitas Lampung, \\ Jl.Sumantri Brojonegoro No. 1 \\ Rajabasa \\ ${ }^{1}$ Email: \\ dedy.hermawan@fisip.unila.ac.id
}

\author{
Simon Sumanjoyo Hutagalung \\ Jurusan Administrasi Negara \\ FISIP, Universitas Lampung, \\ Jl.Sumantri Brojonegoro No. 1 \\ Rajabasa \\ Email: \\ simon.sumanjoyo@fisip.unila.ac.id
}

\author{
Izzul Fatchu Reza \\ Jurusan Administrasi Negara \\ FISIP, Universitas Lampung, \\ Jl.Sumantri Brojonegoro No. 1 \\ Rajabasa \\ Email: izzul.reza@ fisip.unila.ac.id
}

\begin{abstract}
Participation is an approach that became a trend in the design of government programs related to social welfare. Through the participation of community empowerment, impact is expected to appear in addition to the achievement of program outputs. This study aims to determine the forms of participation that emerged from government programs and community behavioral factors that determine the success of participation and community participation model based on behavior that can be raised in order to overcome the problems of participation. The type of research used in this research is descriptive research with qualitative approach and by applying multiple methods of data collection, such as the study of data secondary and observations. Data analysis in this study used Milles and Huberman qualitative data analysis method.
\end{abstract}

This result of the research showed that emerging typology of participation in the management of public participation program in Lampung Province is located in the area of non-participation, risk taking and partnership. Conditions of participation that occurs is also driven by factor of public behavior that consists of three factors, namely; (1) Confidence or a chance to participate. (2 The ability to participate, and (3) Willingness to participate in every activity, which is determined by the presence or absence of the relevant interest. In the end, the participation of behavior-based management model is built by adopting the concept of community engagement and personal engagement.

\section{Keyword: Community Participation, Government Programs, Community Behavioral}

\section{INTRODUCTION}

In the actualization of local governance, especially the implementation of a policy, the participation of the local community which is done on their own will is more needed than the forced participation of the community, as it is the beginning of independence and the development of competence in the government. Governmentled participation also indicates that there is no dominance or hegemony in the government (Kleden, 2004).

Governance can't be implemented effectively if it is not supported by the people who have different social background, education, economy, culture, and sense of awareness that gives influence on the development of government (Mansuri and Rao, 2012). In the context of the participation, society as individuals perform optimally in order to support government policy. Collectively, the community work together to encourage the achievement of government policy in order to achieve 
optimal results. As individuals and collective, society are interconnected in the context of participation (Pelenca, Bassile, and Ceruti, 2015).

The government is encouraging the development in the region through several programs that contain payloads participation. However, a different form is found in the implementation of policies and programs in some sectors, for instance is the education sector, which participation is emerged in the form of election of members of the school committee and the joint planning between the school committee and the school (Menno, et al., 2014). Other example is the tangible participation in waste management collective consciousness to sort garbage, recycle and transform waste into compost (Dhokhikah, Trihadiningrum, and Sunaryo, 2015), poverty (Apriyanti 2011) and forest management (Alfitri, 2005). Planned participation is also appeared in programs of infrastructure development in rural and urban areas.

Various programs such as participation show different symptoms, including raises pseudo participation, the participation of administrative, or even the failure to hold a participation (Muslim, 2017). It also indicates the difference between organic participation (endogenous effort by community activists to bring about change) and participation induced (largescale efforts to devise participation at the local level through programs and projects) (Mansuri and Rao, 2012). In other context, participation occurred also seems that it still not be able to strengthen the relationship between the agency and the collective capabilities that drive collective target group for carrying out the process of participation (Pelenca, Bassile, and Ceruti, 2015).

In the aspect of the relationship, the participation that occurred in the local scope is interesting to be studied. There was an allegation that if participation include personal and group involvement, why do participation in government programs continue to face inoptimal to achieve the desired participation? By trying to limit the scope of research on local government in the province of Lampung, there several problems in this study, namely: (1). What are the forms of public participation that is created in the process of implementation of local government programs? (2) What are the potential people behaviour factors that hinder or encourage the success of community participation in the implementation of program participation on local government? And (3) How can community-based participation model behavior of people in the process of implementing the program on local government? The questions seeks to respond to initial allegations about conditions of participation in government programs.

\section{LITERATURE REVIEW}

Participation is one of the basic fundamental in a democratic system. Mill (1861) stated that participation has been put forward as a proof of participation for the government to satisfy all components of the country where all people can take part. Participation, even in the most smallest public management functions, is useful, and it should exist anywhere as a general agreement for the expected community development (Arblaster, 1987: 63, Bochel, 2006: 11).

Participation as a prerequisite of a democratic society is a premise, in which to become a democratic society, the society must consist of a truly participative institutions (Foltz, 1999). The exercise of authority and power to control the technical decisions show a scope where the public are excluded from the movement that can influence the fate of the society. Society need to influence decision making within the institution in a substantive manner. 
Therefore, the leverage of the participation level could make the institution better (Foltz, 1999).

Meanwhile, Pretty (1995) in Syahri (2016) pointed out that in fact, there are seven characteristics of a typology of participation, which are successively closer to the ideal shape, namely: (1) Passive participation or manipulative: its characteristic is the public receive notice what is and what has been happening. Unilateral announcement by the project implementers do not pay attention to community feedback as the program objectives (Gustavsson, Lindström, Jiddawi, and De La Torre-Castro, 2016). Informative Participation: the society answer some research questions for the project, but they did not have the opportunity to engage and influence the research process (Ford \& King, 2015) while accuracy of the results of the study, was not discussed with the community. (3) Consultative participation: community participate in consultation, while the outsider listen, analyze problems and solve them. There are no opportunities for joint decision-making (Ford \& King, 2015). (4) Incentive Participation: services to the community provided for obtaining payment incentives in the form of wages, although not involved in the learning process or the experiments were carried out (Adhikari, Kingi, and Ganesh, 2014). (5): Functional Participation: people form a group as a part of the project, after major consensus are made. In the early stages, people depend on outsider, but then people gradually show their independence (DiPaola \& TschannenMoran, 2014). (6) Interactive participation: people play a role in the analysis for planning activities and the establishment or strengthening of institutions. The community has a role to control over the implementation of their decisions that have contributed to the overall process of the activities (Conole, 2015). (7) Independent (self-mobilization): people take the initiative themselves freely (not influenced by outsider) to change the system or the values they uphold. Community control over utilization of existing or used resources (Lilleker and KocMichalska, 2017).

Community participation is indispensable as a main condition for the provision of the self-help system, and it also encourage and facilitate the process of development. In relation to participation in the develpoment according to Slamet (1980) in Panggabean (2013) defined participation as the joint activities of the public to provide input in the development, which may include personnel support, materials, funding, expertise, ideas, alternatives and satisfaction, and enjoying the fruits of development as referred by the development goals.

Meanwhile, according to Madrie (1988), people's participation in development is the citizen's participation or involvement in the development process, benefiting the results of development, taking part in the profit, process and outcome of the development, both in the development undertaken by the community, organization or the development by the government itself (Irwan Effendi, 2012:8). From above definition, it can be stated that community participation in development is the community participation in the development in order to improve, accelerate, and ensure the success of development efforts. The community is expected to participate as the result of development that is designed and organized purposively aimed for the welfare of the society itself. The community participation in development is active community participation in the framework of constructive activities to achieve a better state.

Behavior in participation activities essentially is goal-oriented. In other words, our behavior is generally motivated by a desire to achieve a particular goal. The 
specific objectives are not always known consciously by the individual concerned (Winardi, 2004). The definition of behavior as a result of the construction of theories and research is as follows.

a. Behavior is something that is caused by something

b. Behavior is shown towards a specific target

c. Behavior is observably measurable

d. Behaviors that are not directly observed (eg think, implement perception ) is also important in order to achieve the objectives

e. Behavior of conduct motivated

Skinner (1938) in (Muller, 2015) theorized that the behavior is a response or a person's reaction to a stimulus (stimuli from the outside. Therefore, the behavior mainly occurs through the process of the stimulus on the organism and then the organism responds. This response can be divided into two, namely: (a) respondent or reflexive response, that response caused by specific stimulus, for example is a bright light causes the eyes to be closed. These responses include emotional behavior, such as news of the disaster became sad; and (b) operant instrumental response, it is the response that arises and grows, followed by a particular stimulus or incentive. Such behavior will encourage participation at different levels.

\section{METHOD}

The type of research used in this research is descriptive research with qualitative approach. Cresswell in Herdiansyah (2010: 8) stated that qualitative research is a process of scientific research that is intended to understand human problems in a social context by creating a holistic and complex picture, served by reporting the views in detail of the resources, as well as performed in the natural setting ithout any intervention. This study also implementing the Socio Legal Analysis, which seeks to determine the application of the laws on public participation in the implementation of public policies and programs.

The focus of this research are; (1) Categorization of public participation forms in the process of implementation of the program or policy on the local government. (2). Factors of public behavior that inhibit or encourage the success of community participation in the implementation of the participation program, and (3) Model-based public behavior in the process of implementing community participation of local government programs.

This qualitative study applied some common data collection methods, including secondary data and observational studies. Data collection was conducted through interviews with program implementers and program beneficiaries, focus group discussions with stakeholders in the program, and documentary review related to participatory program. The data analysis technique is directed to address the research problem that have been proposed in this proposal. This study used qualitative data analysis method according to Milles and Huberman (1992: 148) by using three analysis components.

\section{RESULTS AND DISCUSSION}

\section{Analysis of Forms of Participation and Determinants of Community Participation-Based Program Success Factors}

This study analyzed three government programs implemented in each local government in Lampung Province:
1. Program Gemma Sewu Bersenyum Manis in Pringsewu Regency
2. National Community Empowerment 
Program (PNPM) Urban in Bandar Lampung

3. Health Promotion Program in East Lampung Regency

Such programs were selected purposively based on the characteristics of the budget, scope of activities and implementation of activities owned by each program format. Gemma program Sewu Bersenyum Manis in Pringsewu Regency is an excellent program which aims to accelerate economic development and make the physical and community participation as an assessment of the program's success (Musyafa, 2017). The analysis results showed that the form of community participation in the planning stage are in the lowest participation level, called as the non participation. During the implementation phase, people are able to mobilize their resources and funding, but they have weak coordination and they couldn't elaborate the program (Yahya, 2017). Forms of community participation in the use of vertical participation of the community is involved in a program and its status as the implementer of the program. In the implementation of this program there are several obstacles ranging from the understanding of the community, lack of funding, water and also lack of coordination in reporting activities.

National Community Empowerment Program (PNPM) for Urban Area is a government program that is substantially seeks to reduce poverty through the concept of people empowerment and developing the area via local actors, including regional governments and local care group, in order to awaken the independent movement of poverty reduction and sustainable development. PNPM Urban prefers this sustainable community development by putting people as the main actors through active participation (Surya, 2017). The results showed that this form of public participation can be observed from public participation in decision-making stage; participation in the implementation phase; community participation in the stage of utilization of the results; and participation in the evaluation phase. Based on it, the community participation in the program is already exist, although it is not comprehensive enough. Community participation through PNPM in Urban Areas is quite good established, and this participation can be categorized as the partnership participation type. (Beny, 2017). At the stage of participation, the government and society are equal partners, where the powers have been delivered to and there have been negotiation process between the people and the authorities, both in terms of decisionmaking, implementation, utilization and monitoring or evaluation.

Health Promotion Program in East Lampung Regency has the village become the answer to the basic needs of public health that can be said to be vital, because all citizens are either rich or poor are entitled and deserve health care (Dwi, 2017). The results of the study shows that the empowerment process and mechanism of health funds management committed by the head of the field of health promotion that is accompanied by a midwife, followed by socialization to Margosari village communities by the village officials. It actually has been running well, but there are still many people who do not yet know clearly about the existence of the health funding program. (Suwardi, 2017).

The success of the process of empowerment and healthy fund management mechanism is supported by the existence of social capital that exist in the community, which consists of high self-awareness and a sense of solidarity and cooperation in improving health standards (Sujono, 2017). Participation in this program is on the risk-taking participation stage,which is now an 
ongoing and evolving process that is not only resulted in the decision, but also to also thinking the outcome of the result regarding the advantages, constraints and implications. At this stage, all of those who concerned about the risks are expected the results of the decision.
From all three programs mentioned, it can be analyzed some of the main factors inhibiting and driving participation program achievements. Such identification can be seen from Table 1 below.

\section{Table 1. Identification of Obstacles or Drivers of the Success Factors of Community Participation-Based Program in Lampung Province}

\begin{tabular}{|c|c|c|c|}
\hline No & PNPM Urban & Health Fund Program & $\begin{array}{c}\text { Program Sewu Bersenyum } \\
\text { Gemma Manis }\end{array}$ \\
\hline \multirow[t]{2}{*}{1} & Limited fundings & Awareness and Solidarity & $\begin{array}{c}\text { Responsive Public } \\
\text { Personnels }\end{array}$ \\
\hline & $\begin{array}{l}\text { Funding for the (physical) } \\
\text { development activities is } \\
\text { perceived lack and the funds } \\
\text { provided were divided into } \\
\text { three stages, which made the } \\
\text { development suspended for a } \\
\text { while. }\end{array}$ & $\begin{array}{l}\text { High self-awareness of the } \\
\text { individuals who participated in this } \\
\text { health funds, as well as solidarity } \\
\text { and cooperation in improving } \\
\text { health standards. }\end{array}$ & $\begin{array}{l}\text { Responsice Village } \\
\text { officials and community } \\
\text { groups to their duties and } \\
\text { functions. }\end{array}$ \\
\hline \multirow[t]{2}{*}{2} & $\begin{array}{c}\text { The low level of public } \\
\text { awareness. }\end{array}$ & \multirow{2}{*}{$\begin{array}{l}\text { Direct Benefits Perceived } \\
\text { Healthy fund activities are also } \\
\text { very beneficial for the Margosari } \\
\text { village community, besides it can } \\
\text { ease the burden when they are } \\
\text { having scourge. }\end{array}$} & $\begin{array}{c}\text { The wrong public } \\
\text { understanding of the } \\
\text { Gemma Sewu Bersenyum } \\
\text { Manis Program }\end{array}$ \\
\hline & $\begin{array}{l}\text { People assumed that PNPM } \\
\text { Urban is the only project of the } \\
\text { government, causing the people } \\
\text { to be less enthusiastic to } \\
\text { participate. }\end{array}$ & & $\begin{array}{l}\text { Gemma Sewu Bersenyum } \\
\text { Manis Program } \\
\text { People who think this } \\
\text { program as a project so they } \\
\text { are reluctant to participate. }\end{array}$ \\
\hline \multirow{2}{*}{3} & Weak Understanding Society & Perceived Impact & \multirow{2}{*}{$\begin{array}{l}\text { Lack of Fundings } \\
\text { People's economs stimulant } \\
\text { funding is still less, because } \\
\text { these funds must also be } \\
\text { distributed into two groups. }\end{array}$} \\
\hline & $\begin{array}{l}\text { Weak understanding of the } \\
\text { community at the time of } \\
\text { administration report making, } \\
\text { caused by the condition that the } \\
\text { citizen are not well-educated. }\end{array}$ & $\begin{array}{l}\text { Healthy fund activity also } \\
\text { increases public knowledge about } \\
\text { important health issues, and } \\
\text { familiarity is also important, so } \\
\text { must each maintain joint health. }\end{array}$ & \\
\hline 4 & $\begin{array}{l}\text { People's Flurry } \\
\text { The flurry of people who can not } \\
\text { take the time to participate in each } \\
\text { activity, eventhough the activity } \\
\text { provides benefit to the community. }\end{array}$ & & $\begin{array}{l}\text { Weak Coordination } \\
\text { Lack of coordination between } \\
\text { community groups with related } \\
\text { PMD activity report }\end{array}$ \\
\hline
\end{tabular}

Source: Data Analysis, 2017.

From the identification of these factors, it can be concluded that there are two aspects, namely institutional and behavioral aspects of the program organizers society that tend to be not optimal to support implementation of the program, so it does not lead to the creation of the effective participation. Therefore, we need a model of participation which based on the people's behavior so as to encourage the achievement of more effective participation. 


\section{Model Behavior-Based Participation In Government Program Implementation}

As a basis for building a model of participation, the contributing factor in community participation needs to be analyzed. These factors, according to Slamet in Salah (2014: 118-119), are as follows. First, the confidence or the opportunity to participate which include; the political will of the government or the authorities to involve the society in development activities, i.e. the decision making process in planning, implementation, maintenance and utilization of the results, the opportunity to gain access to the necessary information, the opportunity to mobilize and utilize resources for the implementation of development, the opportunity to acquire and use appropriate technology including equipment/other equipment including the opportunity to organize themselves to access and use regulation, license, and procedures that should be implemented in the activities and the opportunity to develop leadership which is able to grow, move, develop, and maintain participation. This first factor can be observed in Sewu Bersenyum Manis program in the early non participation stages. This condition is driven by a lack of confidence or opportunity given in the participation.

Second, the ability to participate. The provision of opportunities/ confidence to mobilize public participation will not mean so much if the people themselves do not have the capacity or the ability to take part in development activities. The capability means the ability to understand and to find opportunities to build knowledge or it can be stated as the knowledge about opportunities to improve the quality of life, the technical ability to carry out meaningful activities with respect to the knowledge and technology mastering or skills that must be possessed and also the ability to solve problems by using the resources and opportunities that optimally available. This second factor can be observed in the implementation of urban PNPM program, where people still have a weak understanding of the participation in the program, so that in the end, eventhought there was participation involved in the society with partnership type, but it is not optimal.

Third, the willingness to participate in every activity is determined by the presence or absence of the relevant interest. Interest is a concept that will determine the attitude and behavior if he decides to participate or not. Willingness to participate in the activities concerned with: (1) attitude to abandon old values that impeded improvement of quality of life; (2) the attitude and level of confidence in the government/ authorities; (3) attitude to always be ahead of the present, or not satisfied with the present situation; (4) togetherness in solving the problems collectively; and (5) the attitude of independence or confidence in the ability to improve the quality of life. This third factor could be observed exist in the implementation of health promotion programs in which people are interested to participate because their interests will be assured of better health conditions. Therefore, it can be understood if participation level achieved is at the stage of risk taking.

Based on the above explanation, it can be concluded that the factors that influence the success of public participation can be derived from the individual, namely the willingness and ability, as well as from outside individuals themselves, i.e. the government, economy, and also legality. 


\section{Behavior-Based Participation Management Program Model}

Model of behavior-based participation in program management is built by developing the concept of community engagement and personal engagement. Personal engagement is an expression of physical, cognitive, and emotional elements of people during work. Individuals who engaged are fully understand of the physical, cognitive and emotional in his role (Herbert, 2011). Another opinion expressed by Macey and Schneider (2008) defines engagement as:"an individual's sense of purpose and focused energy, evident to others in the display of personal initiative, adaptability, effort, and persistence directed toward organizational goals". The term of Engagement is interpreted by Macey and Schneider (2008) as a sense of purpose and energy of a person against a purpose and focused energy, showing personal initiative, adaptable, effort, and diligence toward organizational objectives. Engagement is an energetic experience of engagement with personal fulfillment activities which are characterized by energy, involvement, and professional efficacy, as the opposite of the three characteristic of burnout (Demerouti \& Bakker, 2007).

Albrecht (2010) found engagement reflects two quality: (1) a state of positive motivation and energy-related jobs, and (2) a genuine desire to contribute to the work and success of the organization's role. Definition of engagement requires a clear distinction of the betterly conceptualized construct as an antecedent or "driver" or promoting engagement. From all these definitions, it is agreed that engagement is something to be desired, having organizational goals, having psychological and behavioral aspects that involve energy, enthusiasm, and a focused effort (Herbert, 2011). Based on these definitions, it can be concluded that the engagement is a way of looking for someone to be motivated and related to the fulfillment of individual circumstances characterized by energy and high mental resilience during work, enthusiasm, feel important and proud of the work, and focus on enjoying the work.

In the individual dimensions, building a model of community-based participation of behavior associated with the conception of personal resources, which is also the predictors of work engagement. Personal resources is a positive self-evaluation related to resilience and refers to the sense of the individual's ability to control and successfulle impacted the environment (Hobfoll, 2002; Herbert, 2011). Personal resources concept suggests that some positive self-evaluation predicts goal-setting, motivation, performance, job satisfaction, life satisfaction, and other interesting results. The reason is that the greater the personal resources of individuals, the more positive are the individual and the self harmony expected to appear (Judge, 2005; Herbert, 2011). The keyword in that description is the need of strengthening self-efficacy in the design of program participation.

Self-efficacy is the belief in one's ability to organize and execute the parts of the actions required to produce achievement (Bandura, 1997). In addition, Schultz \& Schultz (1994) defines self-efficacy as the feeling of adequacy, efficiency, and ability to cope in life. Baron and Byrne (1994) suggested that self-efficacy is an individual assessment of ability or competence to perform a task, achieve a goal, and produce something. According to Bandura (1997), there are four psychological process in selfefficacy that play a role in humans, namely the process of cognitive, motivational, affective, and the process of election/ selection. The fourth process is later needs to be accommodated in the design of community-based programs. 
In the community dimension, approach to community engagement is a series of steps to involve the public actively in addressing the problem (Swainston \& Summerbell, 2008) as a coalition, or facilitate community workshops. There are three main type of community involvement initiatives, with several initiatives that overlap among others (Attree et al, 2011): (1) area-based initiatives that aim the social and economic disparities; (2) people-based initiatives, which aimed at involving marginalized populations, and (3) coalitionbased initiatives, that aimed at harnessing the power of interest groups. The typology of these initiatives will appear differently on the type of participation program design with its respective characteristics and purpose. The initiative will revolve around the level of involvement, consultation, up to the delegated authority in planning and designing, in order to run collaborative governance or cooperation.

The purpose of this model is to create a fair environment in which individuals, organizations and agencies can work together to address issues of common concern. This model has been used by the Center for Ethnicity and Health at the more than 170 projects, with mixed success (Fountain et al, 2007). In the aspect of community engagement on the design of the program, there are a few main points to ensure the successful implementation of the model;

1. A facilitator that will advertise, recruit, and choose the community organization that would like to participate; Provide and support a team of staff; and encourage the participation of inter and intracommunity.

2. Society organization host has a good relationship with the target communities.

3. Meaningful tasks, limited time and easily manageable. This can be one or all of the circles within the model diagram, which connect communities and institutions in a fair working relationship.

4. Training of members of community organizations as project coordinators.

5. Project support worker who provides support to the community, as directed by the facilitator.

6. Funding support for project activities and personnel.

7. Steering groups should include local planners and service providers/ programs.

In the context of community participation program management, a model that includes both dimensions, i.e. the personal dimension and community dimension are directed at changing individual and group attitudes from their own internal. It is argued that the changes driven from internal self and organization will give a long-term effect. From the description we can describe the behavior-based participation management model as follows. 


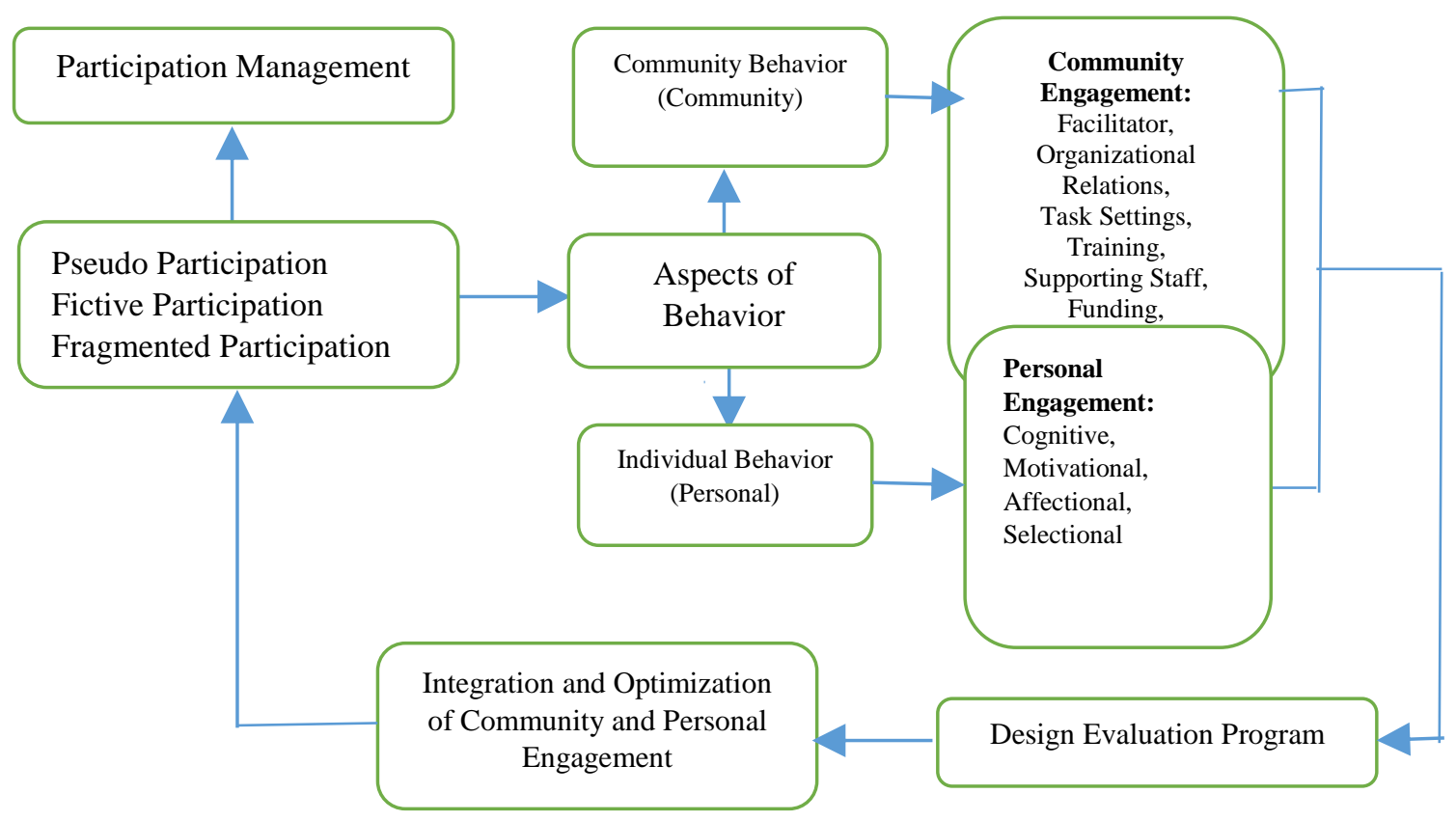

\section{Figure 1. Model of Community-Based Behavior in Participatory Program Management}

This model aims to interfere with the design of less successful programs to create optimal community participation by maximizing the behavioral aspects of individuals and community groups. The Individual and group behaviors that are well understood by the program design will encourage the acceptance and direction of participation creation maximally. Therefore, this model needs to be examined through a social experiment that simulates the program by strengthening the engagement dimension.

\section{CONCLUSION}

Typology of participation that arises in the management of community participation programs are the non participation, risk taking and partnership participation type. This happens because of the variously implementation programs, that have different implementation designs. In well-designed programs, such as PNPM Urban, it has reached the level of partnership although it is not yet optimal to mobilize the community participation. While in programs that are not well designed, such as Gema Sewu Bersenyum Manis, it shows the level of non participation, due to the heavy likeliness of project-oriented program design, hence the participation aspect is not built well.

Condition of participation that occurs is also driven by community behavior factors consisting of three factors form, namely: (1) Trust or opportunity to participate. This first factor can be observed in Gema Bersewu Manis program, which is located at the nonparticiation stage, the condition is driven by lack of trust or opportunity given to participate; (2). Ability to participate. This second factor can be observed in the implementation of the urban PNPM program, where the community still has a poor understanding of participation in the program, so that ultimately, although participation has occurred with the type of partnership but it is still not resulted satisfying, and (3). The willingness to participate in each activities is determined by 
the presence or absence of the interests concerned. This third factor can be observed occurring in the implementation of Health Promotion Program, where people are interested in participating because they are assured of their better health condition. It is, then, very well argued if the level of participation achieved is at the stage of risk taking.

The behavior-based participation management model is built by adopting the concept of community engagement and personal engagement. In the individual dimension, the building of community-based participation model is related to the conception of personal resources which is the predictor of work engagement. The keywords in the description are the necessity of strengthening self efficacy in the design of participation programs. There are four behavioral process in self-efficacy that plays a significant role in human kind, namely the cognitive, motivational, affectional, and the selectional process. These four processes are later need to be accomnodated in the design of community based programs. In the community dimension, the community engagement approach is a series of steps to actively engage communities in dealing with issues, such as forming coalitions or facilitating community workshops. In the aspect of community engagement in the design of participation programs, there are several keypoints to ensure successful application of the model, namely; facilitators, organizational relations, task arrangements, training, support personnel, funds, and referring groups.

\section{Acknowledgment}

Thanks to the Ministry of Research, Technology and Higher Education that has funded this research through a scheme of applied product research grant in 2017. Besides, the author would like to thank the
Institute of Research and Community Service of Lampung University for the support of management so this research can be done.

\section{REFERENCE}

[1] Adhikari, S., Kingi, T., \& Ganesh, S. (2014). Incentives for community participation in the governance and management of common property resources: the case of community forest management in Nepal. Forest Policy and Economics, 1-9.

[2] Alfitri. (2005). Community Based Forestry Based Social Participation Model in Kerinci Seblat National Forest Conservation Program (TNKS). Indonesian Journal For Sustainable Future, 29-42.

[3] Apriyanti. (2011). ANALISIS PROGRAM PEMBERDAYAAN MASYARAKAT DALAM PENANGGULANGAN KEMISKINAN KOTA SEMARANG (Kasus Implementasi Program Pinjaman Bergulir PNPM Mandiri Perkotaan Kelurahan Kemijen Kecamatan Semarang Timur Kota Semarang Tahun 2008-2010). Semarang: Undip.

[4] Arblaster, A. (1987). Democracy (Concept in a Social Science). Bristol: Open University Press.

[5] Beny. (2017). Koordinator Kota Program PNPM [Interview] (23 5 2017).

[6] Bochel,C.(2006).New Labour, Participation and the Policy Process . Public Policy and Administration, 10-22.

[7] Conole, GG (2015). MOOCs as disruptive technologies: strategies for enhancing the learner experience and quality of MOOCs. Revista de Educación a Distancia, 39.

[8] Dhokhikah, Y., Trihadiningrum, Y., \& Sunaryo, S. (2015). Community participation in household solid waste reduction in Surabaya, Indonesia. 
Resources, Conservation and Recycling, 153-162.

[9] DiPaola, M., \& Tschannen-Moran, M. (2014). Organizational citizenship behavior in schools and its relationship to school climate. Journal of School Leadership, 424-447.

[10] Dwi. (2017). Kepala Bidan Promosi Kesehatan di Puskesmas Margototo [Interview] (28 6 2017).

[11] Ford, JD, \& King, D. (2015). A framework for examining adaptation readiness. , Mitigation and Adaptation Strategies for Global Change, 505-526.

[12] Franz, F. (1999). Five Arguments for Increasing Public Participation in Making Science Policy . Buletin of Science, Technlogy and Society, 117127.

[13] Gustavsson, M., Lindström, L., Jiddawi, NS, \& De La Torre-Castro, M. (2016). Procedural and distributive justice in a community-based managed Marine Protected Area in Zanzibar, Tanzania. Marine Policy, 91-100.

[14] Kleden, I. (2004). Masyarakat dan negara: sebuah persoalan. Jakarta: Penerbit Agromedia Pustaka.

[15] Lilleker, DG, \& Koc-Michalska, K. (2017). What drives political participation? Motivations and mobilization in a digital age. Political Communication, 21-43.

[16] Mansuri, G., \& Rao, V. ( 2012). Localizing Development: Does Participation Work? Washington: World Bank Publications.

[17] Menno, P., Suryadarma, D., Beatty, A., Wong, M., Gaduh, A., Alisjahbana, A., \& Artha, RP (2014). Improving Educational Quality through Enhancing Community Participation: Results from a Randomized Field Experiment in Indonesia. American Economic Journal: Applied Economics, 105-126.
[18] Muller, EN (2015). Aggressive Political Participation. Princeton: Princeton University Press.

[19] Muslim, A. (2017). Failure Analysis of the National Program for Community Empowerment in Building Poor SelfReliance (Case Study in Special Province of Yogyakarta, Central Java, and East Java)/ Analisis Kegagalan Program Nasional Pemberdayaan Masyarakat dalam Membangun Kemandirian Masyarakat Miskin (Studi Kasus di Provinsi Daerah Istimewa Yogyakarta, Jawa Tengah, dan Jawa Timur). Jurnal Penyuluhan, 79-87.

[20] Musyafa. (2017). Kepala Desa Parerejo [Interview] (14 5 2017).

[21] Panggabean, R. (2013). PENYULUHAN PERKOPERASIAN DAN UKM. INFOKOP, 120-129.

[22] Pelenca, J., Bassile, D., \& Ceruti, C. (2015). Collective capability and collective agency for sustainability: A case study. Ecological Economics, 226239.

[23] Sujono. (2017). Chief of Health Fund Program [Interview] (29 6 2017).

[24] Surya. (2017). Kasubag of Program Planning in BPMPK Kota Bandar Lampung [Interview] (11 6 2017).

[25] Suwardi. (2017). Head of Margosari Village [Interview] (24 5 2017).

[26] Syahri, M. (2016). Participation Form Of State Citizens In Environmental Sustainability Based On Moral Green Concept In Blitar District/ Bentuk bentuk Partisipasi Warga Negara Dalam Pelestarian Lingkungan Hidup Berdasarkan Konsep Green Moral di Kabupaten Blitar. Jurnal Penelitian Pendidikan, 109-136.

[27] Winardi, J. (2004). Organizational Behavior Management (Manajemen perilaku organisasi). Jakarta: Prenada Media. 